\title{
$\therefore$ An Empirical Study on Changing Trends in Pharmaceutical Sector
}

IJCRR
Section: Healthcare
ISI Impact Factor
(2019-20): 1.628
IC Value (2019): 90.81
SJIF (2020) = 7.893
Cc) (i) ?

\section{Arpita Ghuge ${ }^{1}$, Vaishali Rahate ${ }^{2 *}$, Sapan Joshi ${ }^{3}$, Roshan Kumar Jha ${ }^{4}$}

'Student-Datta Meghe lnstitute Management Studies, Nagpur, India; 'Associate Professor, Datta Meghe Institute Management Studies, Nagpur, India; ${ }^{3}$ Research Scholar, Datta Meghe Institute Management Studies, Nagpur, India; “Tutor Department of Biochemistry Jawaharlal Nehru Medical College, Datta Meghe lnstitute of Medical Sciences Sawangi (Meghe) Wardha, India.

\section{ABSTRACT}

Introduction: Pharmaceutical industry in India is one of the important contributors to the economy of our country, the total industry size forecasted to reach the US $\$ 280$ billion by 2021 . One of the reasons for a high growth rate is attributed to more customer orientation of the promotional strategy of the pharmaceutical companies.

Objective: This research deals with analysing the change in customer orientations.

Methods: 300 Doctors in the Nagpur region were randomly selected and the survey questionnaire consisted of 44 items.

Results: It was observed that the transformation in the pharmaceutical industry is taking place which was proved by applying various statistical techniques like t-test, regression analysis and factor analysis.

Conclusion: The association with the physician is the key to the success of registering the brand with him. More the physician is associated with the company and more time he spends with the executives, the more are the chances of him remembering the brand and prescribing it.

Key Words: Pharmaceutical sector, Promotion, Customer orientation

\section{INTRODUCTION}

The pharmaceutical industry, like any other industry, is very dynamic. There had been many changes and in many forms of its operations. In terms of size, India's pharmaceutical sector accounts for about $2.4 \%$ of the global pharmaceutical industry and $10 \%$ in terms of production. India accounts for $20 \%$ of global generics exports. ${ }^{1}$ The various aspects of the industry can be studied for the change, but this research consists of two main perspectives that are the "role of marketing of product" and "the approach of pharmaceutical professionals".

In the "role of marketing of product", we try to understand the new approach of industry towards their customer i.e. the doctor. The role of corporate is studied and their contribution is analyzed in generating sales for the company. The preference of doctor is studied how they think about a company when a pharmaceutical executive approaches the doctor. ${ }^{1,2}$

From the point of view of "pharmaceutical professionals", we have tried to understand various factors affecting doctor's prescription. Here some interpersonal attributes are studied to understand the reason for a doctor's prescription for a brand, how technology is playing its part and is the customer-specific segmentation is affecting the prescription pattern.

\section{MATERIALS AND METHODS}

\section{Study design}

The type of research design followed for the study is Exploratory Research. The study was conducted on doctors by snowball method sampling technique. The sample size was 300 doctors of Nagpur city. The main criteria were to select those doctors who get a regular visit from the medical representatives of various companies. Primary data was collected through questionnaires and Interview methods. Secondary data was collected through various websites and literature review.

\section{Corresponding Author:}

Dr. Vaishali Rahate, Associate Professor, Datta Meghe Institute Management Studies, Nagpur, India.

ISSN: 2231-2196 (Print)

Received: 12.10 .2020
ISSN: 0975-5241 (Online)

Revised: 15.11 .2020
Accepted: 10.01 .2021
Published: 19.05 .2021 


\section{Objectives:}

1. To understand the current behavioural trend of the pharmaceutical companies towards their customers (Doctors/Physicians).

2. To understand the preference of physicians/Doctors to recommend the local pharmaceutical company or multinational company

3. To study the various factors affecting the intention of a doctor to prescribe a drug.

\section{Statistical analysis}

The analysis was done in SPSS. The test was conducted using Statistical Package for Social Sciences 21 on 303 responses received after gathering primary data (Table 1). The score obtained is 0.959 which is more than 0.9. As per the table above we can say that there is excellent internal consistency among all the 44 variables.

Table 1: Reliability testing Reliability Statistics Cronbach'sAlpa

\begin{tabular}{llcc}
\multicolumn{4}{c}{ Reliability } \\
Case Processing Summary \\
\multirow{2}{*}{ Cases } & Nalid & 299 & $\%$ \\
& Excluded & 4 & 98.7 \\
& Total & 303 & 1.3 \\
& & 100.0 \\
\hline
\end{tabular}

a. List wise deletion based on all variables in the procedure.

Reliability Statistics

Cronbach's Alpha

No. of Items

0.959

44

\section{RESULT AND DISCUSSION}

Total $43.6 \%$ of total respondents agreed to the fact that they are experiencing a transformation in the pharmaceutical sector. $76.5 \%$ of total respondents agreed that they discuss a new molecule with MR during launch. $72 \%$ of the respond- ents agreed that Company image influences their prescription. $79 \%$ of the respondents agreed that innovative drug delivery system and packaging influences their prescription. ${ }^{3}$

Only $11 \%$ of the respondents agreed that the Size of the tablet and the taste of the products influence their prescription.69.7 $\%$ of the respondents think communication of field staff with retailer/chemist plays an important role in the successful promotion of brands. $73.9 \%$ of total respondents agreed that the companies conduct different campaigns in your clinic/hospital. $77.2 \%$ of the respondents agreed that companies send mailer or samples or updates to you regularly. $81.5 \%$ of the respondents agreed that personalized communication from corporate affects their prescriptions. $72 \%$ of the respondents agree that companies have increased their communication with you in the last 2 to 3 years.

$68 \%$ of the respondents opine that companies are reducing their dependence on MR for regular communication and inputs. $79 \%$ of the respondents agree that information exposure to internet / TV/ print media has made the patient more aware and do you think this has influenced patients to comply with the dosage and duration of medicine prescribed.

$72 \%$ of the doctors think that brand recollection is simplified because of division wise Therapeutic segmentation of products by companies. Amongst the various attributes of MR such as Product knowledge of MR, Communication skills of MR, New information with MR, relations with MR, Punctuality and regularity of MR, Visit with a senior manager from the head office of the company, Product knowledge and visit of senior manager has an impact to influence the prescription of the drug. ${ }^{4,5}$

\section{Hypothesis Testing}

The "Model Summary" indicates an $\mathrm{R}^{2}$ value of 0.466 , which means that the linear regression explains $46.6 \%$ of the variance in the data. The Durbin-Watson $d=1.950$, which is between the two critical values of $1.5<\mathrm{d}<2.5$ and therefore we can assume that there is no first-order linear auto-correlation in the data (Table 2).

Table 2: One-Sample Test

\begin{tabular}{|c|c|c|c|c|c|}
\hline \multirow{2}{*}{\multicolumn{6}{|c|}{$\begin{array}{l}\text { One-Sample Test } \\
\text { One-Sample Statistics }\end{array}$}} \\
\hline & & & & & \\
\hline & $\mathbf{N}$ & Mean & $\begin{array}{l}\text { Std. De- } \\
\text { viation }\end{array}$ & $\begin{array}{l}\text { Std. Error } \\
\text { Mean }\end{array}$ & \\
\hline$V_{1}$ & 303 & & 4.14 & .893 & .051 \\
\hline$V_{2}$ & 303 & & 3.48 & .948 & .054 \\
\hline$V_{3}$ & 303 & & 3.77 & .860 & .049 \\
\hline$V_{4}$ & 303 & & 3.83 & .949 & .054 \\
\hline$V_{5}$ & 303 & & 3.83 & .917 & .053 \\
\hline V6 & 303 & & 3.77 & .931 & .053 \\
\hline
\end{tabular}




\begin{tabular}{|c|c|c|c|c|c|c|c|}
\hline $\mathrm{V}_{7}$ & 303 & 3.70 & & .056 & & & \\
\hline V8 & 303 & 3.47 & & .061 & & & \\
\hline V9 & 303 & 3.79 & & .052 & & & \\
\hline V10 & 303 & 3.93 & & .055 & & & \\
\hline V11 & 303 & $3 \cdot 97$ & & .054 & & & \\
\hline V12 & 303 & 3.91 & & .059 & & & \\
\hline \multicolumn{8}{|c|}{ One-Sample Test } \\
\hline & & \multirow{3}{*}{$\mathbf{t}$} & \multirow{3}{*}{ df } & \multicolumn{2}{|l|}{ Test Value $=1$} & \multirow{2}{*}{\multicolumn{2}{|c|}{$\begin{array}{l}95 \% \text { Confidence Interval } \\
\text { of the Difference }\end{array}$}} \\
\hline & & & & Sig. (2-tailed) & $\begin{array}{l}\text { Mean Dif- } \\
\text { ference }\end{array}$ & & \\
\hline & & & & & & Lower & Upper \\
\hline$V_{1}$ & & 61.235 & 302 & .000 & 3.142 & 3.04 & 3.24 \\
\hline $\mathrm{V}_{2}$ & & 45.437 & 302 & .000 & 2.475 & 2.37 & 2.58 \\
\hline$V_{3}$ & & 56.122 & 302 & .000 & 2.772 & 2.68 & 2.87 \\
\hline $\mathrm{V}_{4}$ & & 51.843 & 302 & .000 & 2.825 & 2.72 & 2.93 \\
\hline $\mathrm{V}_{5}$ & & 53.650 & 302 & .000 & 2.825 & 2.72 & 2.93 \\
\hline V6 & & 51.765 & 302 & .000 & 2.769 & 2.66 & 2.87 \\
\hline $\mathrm{V}_{7}$ & & 48.581 & 302 & .000 & 2.703 & 2.59 & 2.81 \\
\hline V8 & & 40.601 & 302 & .000 & 2.465 & 2.35 & 2.58 \\
\hline $\mathrm{V}_{9}$ & & $53 \cdot 303$ & 302 & .000 & 2.789 & 2.69 & 2.89 \\
\hline Vio & & 53.654 & 302 & .000 & 2.927 & 2.82 & 3.03 \\
\hline$V_{11}$ & & 54.764 & 302 & .000 & 2.974 & 2.87 & 3.08 \\
\hline$V_{12}$ & & 49.609 & 302 & .000 & 2.914 & 2.80 & 3.03 \\
\hline
\end{tabular}

Ho1: There is no changed attitude of the Pharmaceutical companies towards their customers.

Ha1: There is a changed attitude of the Pharmaceutical companies towards their customers.

Each variable from V1 to V12 show a significant difference between each variable's mean and test value. This difference is statistically significant as indicated by the $p$-value of each variable which is less than 0.05 at a $95 \%$ significance level. This indicates that the null hypothesis is rejected and the alternate hypothesis is accepted (Table 3).

Table 3: Regression analysis was done to understand the variance in data

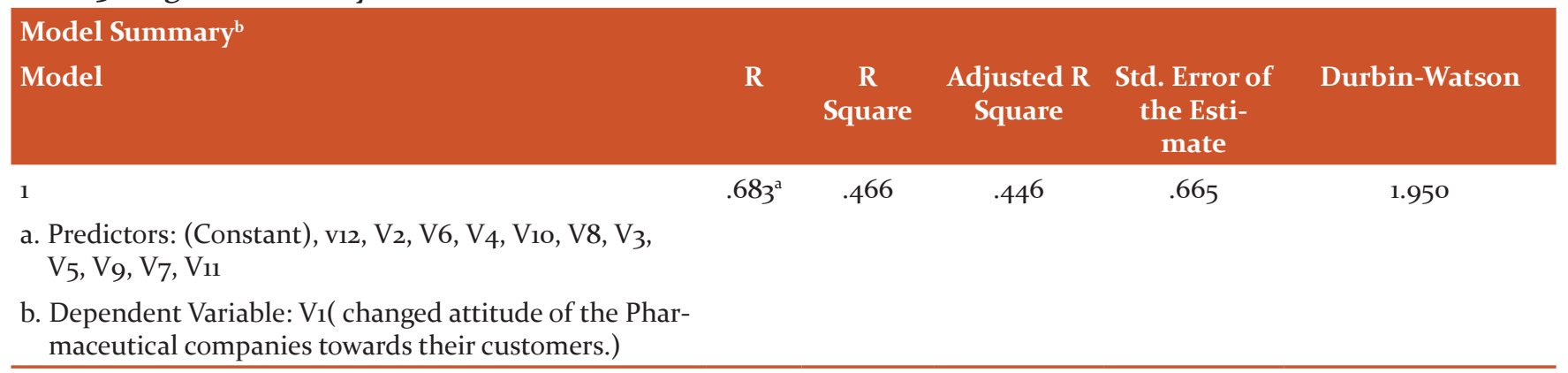

The above discussion proves that there is a changed attitude of the Pharmaceutical companies towards their customers. ${ }^{3}$

HO2: Physicians have a preference for the local pharmaceutical company over a multinational company

Ha2: Physicians are unbiased towards the local pharmaceutical company or multinational company.
From the t-test conducted we see $\mathrm{p}$ values less than 0.05 at a $95 \%$ confidence level. This suggests that there is a difference between the mean and the test value which is significant. Hence we can conclude that the null hypothesis is rejected and the alternate hypothesis is accepted (Table 4). 
Table 4: One sample Test

\begin{tabular}{|c|c|c|c|c|c|c|}
\hline \multicolumn{7}{|c|}{ One-Sample Test } \\
\hline & \multirow{3}{*}{$\mathbf{t}$} & \multirow{3}{*}{ Df } & \multirow{3}{*}{$\begin{array}{c}\text { Significance } \\
\text { (2-tailed) }\end{array}$} & \multicolumn{2}{|l|}{ Test Value $=\mathbf{5}$} & \\
\hline & & & & Mean Difference & \multicolumn{2}{|c|}{$95 \%$ Confidence Interval of the Difference } \\
\hline & & & & & Lower & Upper \\
\hline $\mathrm{V}_{40}$ & -23.565 & 302 & .001 & -1.409 & -1.53 & -1.29 \\
\hline $\mathrm{V}_{41}$ & -25.189 & 302 & .001 & -1.439 & -1.55 & -1.33 \\
\hline $\mathrm{V}_{42}$ & -27.603 & 302 & .001 & -1.551 & -1.66 & -1.44 \\
\hline $\mathrm{V}_{43}$ & -29.568 & 302 & .001 & -1.531 & -1.63 & -1.43 \\
\hline $\mathrm{V}_{44}$ & -35.824 & 302 & .001 & -1.736 & -1.83 & -1.64 \\
\hline
\end{tabular}

This indicates that the physicians are unbiased towards the local pharmaceutical company or multinational company. The last variable number 44 shows a p-value less than 0.05 and thus the difference is statistically significant as compared to the test value. This suggests that there is no much difference in the marketing strategy of local and multinational companies. The above analysis concludes that the physicians are unbiased towards local or multinational companies and there is no much difference in marketing strategy between them.

\section{Table 5: KMO and Bartlett's Test}

\section{KMO and Bartlett's Test}

Kaiser-Meyer-Olkin Measure of Sampling Adequacy 0.882

Bartlett's Test of Sphericity

Approx. Chi-Square

$\mathrm{df}$

Sig.
1076.239

55

.000

\section{Table 6: Total Variance}

\begin{tabular}{|c|c|c|c|c|c|c|c|c|c|}
\hline \multicolumn{10}{|c|}{ Total Variance Explained } \\
\hline Component & $\begin{array}{l}\text { Initial Eigen- } \\
\text { values }\end{array}$ & $\begin{array}{c}\text { Extrac- } \\
\text { tion Sums } \\
\text { of Squared } \\
\text { Loadings }\end{array}$ & $\begin{array}{l}\text { Rotation } \\
\text { Sums of } \\
\text { Squared } \\
\text { Loadings }\end{array}$ & & & & & & \\
\hline & Total & $\begin{array}{l}\% \text { of Vari- } \\
\text { ance }\end{array}$ & $\begin{array}{c}\text { Cumulative } \\
\%\end{array}$ & Total & $\begin{array}{l}\% \text { of Vari- } \\
\text { ance }\end{array}$ & $\begin{array}{c}\text { Cumulative } \\
\%\end{array}$ & Total & $\begin{array}{l}\% \text { of Vari- } \\
\text { ance }\end{array}$ & $\begin{array}{c}\text { Cumulative } \\
\%\end{array}$ \\
\hline 1 & 4.504 & 40.947 & 40.947 & 4.504 & 40.947 & 40.947 & 3.793 & 34.482 & $34 \cdot 482$ \\
\hline 2 & 1.296 & 11.777 & 52.724 & 1.296 & 11.777 & 52.724 & 2.007 & 18.242 & 52.724 \\
\hline 3 & 0.899 & 8.171 & 60.895 & & & & & & \\
\hline 4 & 0.815 & 7.405 & 68.300 & & & & & & \\
\hline 5 & 0.770 & 7.004 & $75 \cdot 304$ & & & & & & \\
\hline 6 & 0.555 & 5.048 & 80.352 & & & & & & \\
\hline 7 & 0.519 & 4.721 & 85.073 & & & & & & \\
\hline 8 & 0.476 & 4.328 & 89.401 & & & & & & \\
\hline 9 & 0.438 & 3.982 & 93.383 & & & & & & \\
\hline 10 & 0.373 & 3.390 & 96.772 & & & & & & \\
\hline 11 & 0.355 & 3.228 & 100.000 & & & & & & \\
\hline
\end{tabular}

Extraction Method: Principal Component Analysis. 
Table 7: Rotated Component Matrix

\begin{tabular}{lcc} 
Rotated Component Matrix & & \\
& Component & \\
V24 Commitment & 0.566 & 0.176 \\
V25 Visit with senior & 0.580 & 0.396 \\
V26 Presentation skills & 0.650 & 0.382 \\
V27 Communication skills & 0.694 & 0.156 \\
V28 Product knowledge & 0.616 & 0.405 \\
V29 Updated Information & 0.765 & 0.141 \\
V30 Frequent visits & 0.224 & 0.764 \\
V31 Comparative analysis & 0.809 & \\
V32 Visit with Zonal head & 0.317 & 0.681 \\
V33 Presenting gifts & 0.387 & 0.646 \\
V34 Networking activities & 0.561 & \\
\hline
\end{tabular}

Extraction Method: Principal Component Analysis. Rotation Method: Varimax with Kaiser Normalization.

a. Rotation converged in 3 iterations.

From the variables of component 1, we can say that "Professional" MR influences the prescription pattern of the physician. From the variables of component 2, we can say that "Experienced and matured" field staff of any gender influences the prescription equally of a physician. Two new factors are found out from the above factor analysis. One is "Professional" and the second is "Experienced and Matured" field staff of any gender. ${ }^{6}$

\section{CONCLUSION}

This study was undertaken to be useful to those who want to launch a new molecule by any pharmaceutical company, or launch a new molecule in the market or want to study the dynamics of the industry. The association with the physician is the key to the success of registering the brand with him. More the physician is associated with the company and more time he spends with the executives, the more are the chances of him remembering the brand and prescribing it. The physicians are therefore invited to attend various programs like CME (Continues Medical Education) workshops, seminars etc. by which they are associated with the company and spend more time with the company executive. This activity registers the brand and increases business for the company. Therapy wise segmentation of the products or brands increases the chances of registration of brand with the physician. It becomes difficult for the physician to remember brands if not associated with any segment.

\section{Conflict of Interest: Nil}

Source of Funding: Nil

\section{REFERENCES}

1. Erdinc O, Vayvay O. Ergonomics interventions improve quality in manufacturing: a case study. Int J Ind Syst Engg 2008;3:727745.

2. Kim Y, Kang D, Koh S. Risk factors of work-related musculoskeletal symptoms among motor engine assembly plant workers. Korean J Occup Environ Med 2004;16(4):488-498.

3. Gentzler M, Stader S. Posture stress on fire-fighters and emergency medical technicians (EMTs) associated with repetitive reaching, bending, lifting, and pulling tasks. Work 2010;37(3): 227-239.

4. Jones T, Kumar S. Comparison of ergonomic risk assessments in a repetitive high-risk sawmill occupation: Saw-filer. Int J Ind Ergon 2007;37(9-10):744-753.

5. Janowitz I, Gillen M, Ryan G. Measuring the physical demands of work in hospital settings: Design and implementation of an ergonomics assessment. Appl Ergon 2006;37(5):641-658.

6. Choobineh A, Tabatabaee S, Behzadi M. Musculoskeletal problems among workers of an Iranian sugar-producing factory. Int J Occup Saf Ergon 2009;15(4):419-24. 